\title{
Myogenic Progenitor Cell Differentiation Is Dependent on Modulation of Mitochondrial Biogenesis through Autophagy
}

\author{
Yoshimi Hiraumi, Chengqun Huang, Allen M. Andres, Ying Xiong, \\ Jennifer Ramil, and Roberta A. Gottlieb
}

\begin{abstract}
Over the last decade, stem/progenitor cell therapy has emerged as an innovative approach to promote cardiac repair and regeneration. However, the therapeutic prospects of are currently limited by inadequate means to regulate cell proliferation, homing, engraftment, and differentiation. Autophagy, a lysosomemediated degradation pathway for recycling organelles and protein aggregates, is recognized as important for facilitating cell differentiation. Studies have shown that induced pluripotent stem cells (iPCs), which exhibit a predominantly glycolytic metabolism, shift toward oxidative mitochondrial metabolism as a prerequisite for the formation of sarcomeres and differentiation into cardiomyocytes. C2C12 myoblasts are a mouse-derived myogenic progenitor cell line which can be induced to differentiate into myotubes. We hypothesize that autophagy is essential in coordinating transcription factor activity and metabolic reprogramming of mitochondria to support myocyte differentiation.
\end{abstract}

\section{Keywords}

Autophagy $\bullet$ Stem cell $\bullet$ Differentiation

C2C12 myoblasts were cultured in DMEM (10\% FBS) and induced to differentiate into myotubes with DMEM (2 \% horse serum) for 6 days. To disrupt autophagy, cells were (1) transfected with $50 \mathrm{nM}$ Atg5 siRNA for $8 \mathrm{~h}$ twice over a $48 \mathrm{~h}$ period

\footnotetext{
Y. Hiraumi $(\bowtie)$

Department of Pediatrics Cardiology, Hyogo Amagasaki Prefecture Hospital, Higashidaimotsucyo 1-1-1, Amagasaki, Hyogo 660-0828, Japan

e-mail: hirahira@kuhp.kyoto-u.ac.jp

C. Huang • A.M. Andres • Y. Xiong • J. Ramil • R.A. Gottlieb

Donald P. Shiley BioScience Center, San Diego State University, 5500 Campanile Drive, San Diego, CA 92182-4650, USA
}

T. Nakanishi et al. (eds.), Etiology and Morphogenesis of Congenital Heart Disease, DOI 10.1007/978-4-431-54628-3_15 


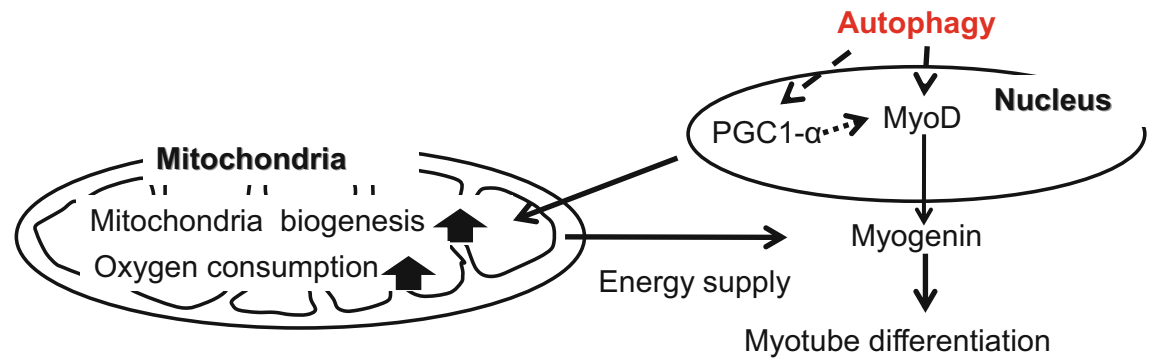

Fig. 15.1 Proposed mechanism for the role of autophagy in $\mathrm{C} 2 \mathrm{C} 12$ cell differentiation. Upregulation of PGC1 $\alpha$, MyoD, and myogenin is a hallmark of cell differentiation. Transcription factor regulation by autophagy may affect mitochondrial turnover required for $\mathrm{C} 2 \mathrm{C} 12$ cell differentiation. Autophagy is essential for coordinating transcriptional regulation and mitochondrial dynamics to support the progression of cell differentiation

or (2) treated with $10 \mathrm{nM}$ bafilomycin A1 or vehicle control for a $3 \mathrm{~h} /$ day for the first 3 days of differentiation. GFP-LC3 adenovirus was employed to visualize autophagy. Western blot and real-time qPCR were used to examine proteins and transcripts of interest. We observed increased LC3-II levels and GFP-LC3 puncta during the differentiation of $\mathrm{C} 2 \mathrm{C} 12$ cells, suggesting the involvement of autophagy in this process. Transient inhibition of autophagy during the early stages of differentiation with either Atg5 siRNA or bafilomycin A1 interfered with myotube formation and attenuated the upregulation of myogenic transcription factors MyoD and myogenin. Differentiation was accompanied by an increase in PGC1 $\alpha$ mRNA, mitochondrial mass, and oxygen consumption, all of which were blocked by disruption of autophagy. Autophagy coordinates transcription factor expression and mitochondrial turnover essential for cell differentiation (Fig. 15.1).

Open Access This chapter is distributed under the terms of the Creative Commons AttributionNoncommercial 2.5 License (http://creativecommons.org/licenses/by-nc/2.5/) which permits any noncommercial use, distribution, and reproduction in any medium, provided the original author(s) and source are credited.

The images or other third party material in this chapter are included in the work's Creative Commons license, unless indicated otherwise in the credit line; if such material is not included in the work's Creative Commons license and the respective action is not permitted by statutory regulation, users will need to obtain permission from the license holder to duplicate, adapt or reproduce the material. 